DOI: https://doi.org/10.32653/CH154751-768

Saida M. Garunova, Junior Researcher, G. Tsadasa Institute of Language, Literature and Art of the Daghestan Federal Research Centre of RAS, Makhachkala, Russia saida-mag@yandex.ru

Robert Chenciner, Honorary Researcher, Prof., St. Antony's College, University of Oxford, United Kingdom chenciner@clara.net

Alexander N. Sadovoy, D.Sc. (in History), Prof., Head of Dept. of Laboratory of Ethnosocial problems Sochi Research Center of the RAS, Sochi, Russia sadovoy.a.n@gmail.com

Magomedhan M. Magomedhanov, D.Sc. (in History), Prof., Head of Dept. of Ethnography, The Institute of History, Archaeology and Ethnography of the Daghestan Federal Research Centre of RAS, Makhachkala, Russia mkhan@yandex.ru

Alexander V. Bakanov Junior Researcher The Institute of History, Archaeology and Ethnography of the Daghestan Federal Research Centre of RAS, Makhachkala, Russia mr.bakanov85@mail.ru

\title{
MONETIZING THE MOUNTAINS: TOWARDS THE STUDY OF ETHNO-CULTURAL AND DEMOGRAPHIC ASPECTS OF THE SOCIO-ECONOMIC DEVELOPMENT OF THE MOUNTAIN DAGESTAN
}


DOI: https://doi.org/10.32653/CH154751-768

Гарунова С.М., младший научный сотрудник, Институт языка, литературы и искусства им. Г. Цадасы Дагестанского федерального исследовательского центра РАН, Махачкала, Россия saida-mag@yandex.ru

Роберт Ченсинер, почетный научный сотрудник, проф., Колледж Св. Антония,Оксфордский университет, Великобритания chenciner@clara.net

Садовой А.Н., д.и.н., проф., заведующий лабораторией этносоциальных проблем Сочинского научного центра РАН, Сочи, Россия sadovoy.a.n@gmail.com

Магомедханов М.M., д.и.н., заведующий отделом этнографии, Институт истории, археологии и этнографии Дагестанского федерального исследовательского центра РАН, Махачкала, Россия mkhan@yandex.ru

Баканов А.В.

младший научный сотрудник

Институт истории, археологии и этнографии Дагестанского федерального исследовательского центра РАН, Махачкала, Россия mr.bakanov85@mail.ru

\section{МОНЕТИЗАЦИЯ ГОР: \\ К ИЗУЧЕНИЮ ЭТНОКУЛЬТУРНОГО И ДЕМОГРАФИЧЕСКОГО АСПЕКТОВ СОЦИАЛЬНО-ЭКОНОМИЧЕСКОГО РАЗВИТИЯ ГОРНОГО ДАГЕСТАНА}

(C) Гарунова С.М., Ченсинер Р., Садовой А.Н., Магомедханов М.М., Баканов А.В., 2019 (C) Дагестанский федеральный исследовательский центр РАН, 2019

(ङ) Creative Commons Attribution 4.0 International License 
Abstract. This article aims at a preliminary study of the status and prospects of the use of the ethnocultural and demographic potential of Dagestan in the recreational and socio-economic development of Mountainous areas of the North Caucasus region, so-called mountain tourism for example spas, sanatoria, skiing, climbing, trekking and handicrafts.

The perspectives of development of recreational opportunities in the North Caucasus are strongly connected with the population mobility and the stability of the ethnic-social situation and so have to be considered in the context of inter-ethnic (economic and cultural) communications of largely outsider authorities and inhabitants on regional and international levels. In this sense, acknowledgement of the country its culture, an introduction to the history of traditional economic specialization and its evolution, traditional customs and ethnic particularities, seems very important.

The practical, social significance of the development of recreational potential is determined by its metaphysical place in the preservation of historical-cultural and natural heritage: traditional social-support systems, economic specialization, and the handicraft centres. Ignored by previous researchers, the fact that the phenomena of "ethnic economy", "ethnic entrepreneurship" and "preservation of traditional social institutions" of the peoples of the Caucasus (in this case) can be traced at all stages of their history, manifesting its exceptional stability during periods of change, such as local forms of government, changes of political regimes and ideological systems. Moreover, it is often ignored that the actual problems of integration of these social institutions into 'state-modernized' Russian society are the basic factors or reasons for destabilizing the system of interethnic relations.

This occurs especially in areas where various forms of ethnic entrepreneurship are represented by first- or second-generation often forced migrants.

We propose a practical approach to advising local good policy.

Keywords: Dagestan; North Caucasus; Dagestan Mountain peoples; ethnocultural development; demographic history; ethno-economy; recreation; Mountain tourism.

Аннотация. Целью данной статьи является предварительное изучение состояния и перспектив использования этнокультурного и демографического потенциала Дагестана в рекреационном и социально-экономическом развитии горных районов Северо-Кавказского региона, например, так называемого горного туризма: курорты, санатории, горные лыжи, альпинизм, пешие походы, рукоделие.

Перспективы развития рекреационных возможностей на Северном Кавказе тесно связаны с мобильностью населения и стабильностью этносоциальной ситуации и поэтому должны рассматриваться в контексте межэтнических (экономических и культурных) коммуникаций в основном со сторонними властями и жителями на межрегиональном и международном уровнях. В этом смысле признание региона с ее культурой, знакомство с историей традиционной экономической специализации и ее эволюцией, традиционными обычаями и этническими особенностями представляется очень важным.

Проигнорированные предыдущими исследователями факты и явления «этнической экономики», «этнического предпринимательства» и «сохранения традиционных социальных институтов» народов Кавказа (в данном случае) прослеживаются на всех этапах их истории, проявляя свою исключительную устойчивость в периоды перемен, таких как местные формы правления, изменения политических режимов и идеологических систем. Более того, частое игнорирование актуальных проблем интеграции этих социальных институтов в «модернизированное государством» российское общество является основным фактором, причиной дестабилизации системы межэтнических отношений.

Это происходит особенно в тех районах, где различные формы этнического предпринимательства представлены часто вынужденными переселенцами первого или второго поколения. Мы предлагаем практический подход и рекомендации для местной политики.

Ключевые слова: Дагестан; Северный Кавказ; дагестанские горцы; этнокультурное развитие; демографическая история; этно-экономика; рекреация; горный туризм. 


\section{Introduction}

State thinking about the recreational development of territories is traditionally "monopolized" by outsider economists and sociologists who are usually focused on the exclusive study of modern socio-economic processes and resulting social consequences and problems. At the same time, socio-economic processes are not considered in conjunction with cultural geography, ethnic processes or dynamics of changes in the course of social, national and environmental policies. As a result, the "ethnic" component of the concept itself is not used by economists and sociologists to identify the mechanism (cause-effect relationships) of the exceptional sustainability of traditional systems of environmental management and economic specialization of ethnic groups. Instead, local ethnic groups (in some cases, Diasporas) are designated as the protagonists of modern economic processes.

The Russian media, negatively commenting on ethnic entrepreneurship (typically market traders) and ethnic crime in its megacities (comparing with Western countries), clearly underestimates the fact that it is not only a form of assimilation of migrants but also an intra-regional and inter-regional system of economic relations. It further ensures sustainable development of Mountain regions where the economy is based on traditional models of nature management, livelihoods, preservation of historical and cultural heritage in food production and other consumer goods. In this context, we examined the problems of adaptation of ethnocultural peculiarities to and with contemporary social and economic realities related to tourism development related to the relevant cultural geography of the Caucasus.

\section{Historiography}

It should be noted that in Western historiography, "ethnic economics" refers to those sectors of the urban economy that are mastered by first-generation migrants. Starting with the early 2oth century researches of Robert Ezra Park (1864-1944), it has become traditional to represent this social group as "marginalized". Most of the concepts of "ethnic economy" are based on the assumption that migrants find themselves isolated in their specific situation. Park was a leader of the Chicago school of sociology fl. 1914-1933, which inter alia was first to define the four components of the race relations cycle.

On the one hand, they find themselves in the "losing" position of the minority, and on the other, they have at their disposal additional resources, which are commonly called "ethnic".

Such an ethnic resource becomes a kind of "social capital", i.e. an economic and/ or political resource based on the "inclusion" of a person in a network of mutual acquaintances and ties, in this case, based on ethnicity (Light, I., Karageorgis, S. [1, p. 646-671], concluded that ethnic groups were largely only effective in business because they used formal and informal mutual support from ready-made ethnic networks. 
According to Mark Granovetter (b. 1943 of Stamford University USA), social networks are not strictly fixed. They are the social context of the business and can be activated by different needs [2].

Such situational definitions serve as the basis for building the ethnocultural boundaries of commercial enclaves (according to F. Barth (1928 to 2016 of Boston, Oslo, Cambridge universities), as follows.

An ethnic enclave (in the form of a network of connections and/or territory of concentrated residence), based on ethnic business, grows into a powerful corporation with an expanding set of interests not only in the economy, but also in politics and, accordingly, expanding the network of relations of its representatives at key positions of the host society [3]. We have found this with the Daghestani Diaspora in Turkey who generously entertained us to dinner in Ankara in 2018.

In the light of these ideas, it is also instructive to consider the strategies for the resettlement of migrants in modern urban environments, often studied by foreign (i.e. non-Russian) researchers.

Most interesting to us are the works of Prof. Ceri Peach (1939-2018), which describe the patterns of resettlement of West Indian migrants to the UK [4].

The traditional social status, level of education, social attitudes of migrants as carriers of "traditional values", and culture in the urban environment of a different society and ethnic culture, as a rule, are not considered either in Russian or foreign historiography.

It is strange that traditional social institutions and the systems of communication relations (and not only with the place of origin), which migrants, as ethnic minorities, are consciously trying to maintain, remain beyond the scope of academic concern.

This determined the academic approach in which ethnic entrepreneurship is very often seen as a reaction of ethnic minorities (so-called "marginal groups") to permanent discrimination by the ethnic majority. It is also conversely identified infrequent exclusion from conventional and so higher prestige careers.

The formation of enclaves of "trade minorities" is often considered in the context of their intermediary functions between "producers" (of goods) and "buyers" representing the ethnic majority.

The economic feasibility of organizing such cooperation based on ethnic selfidentification, according to several foreign (non-Russian) researchers, is global.

For example, in a study by Edna Bonachich [5], it was illustrated by the examples of the Diasporas of the Jews, Chinese, Indians, Armenians, and several other peoples.

The subsequent classifications of ethnic economics (R. Waldinger [6; 7], I. Light and S. Karagergis [1] and others), adopted by Russian authors V.V. Radaev [8], N.P. Ryzhova [9], A. Snisarenko [10] proceed from the same considerations: migrants are permanently in a "disadvantaged" position typical of a minority.

The formation of special "ethnic" and social (economic) networks based on "trust" is seen as a reaction to the perceived hostile external environment.

The goal of the migrants to reduce possible transaction costs associated with "distrust" (for example, by using intermediaries). For example, China the world's largest honey producer in 2019 routes honey through 20 countries to the UK. 
In the same context, ethnic entrepreneurship is seen as a cost-effective form and method of developing the territory under its traditional economic structure, including the formation of penetration-assimilation mechanisms, control and organized resettlement.

\section{Some notes on Methodology}

In the literature, there is the implicit acceptance that ethnic entrepreneurs are literally a group aimed at forced accumulation of capital by any means, to capture and hold on to markets. They are merged with the criminal world and exist everywhere on the borders between the legal and shadow economies [1; 12, p. 141].

High level of competitiveness in economic sectors is usually considered as an aggressive "expansion".

According to the Russian media, both factors cause the spread in the city enclave of a new range of "phobias", which objectively must destabilize the system of interethnic relations.

The second aspect of the analysis of the forms of economic activity of ethnic minorities in countries undergoing the stages of industrial and post-industrial development is related to solving the problems of integration of small ethnic groups.

Following Franz Brentano (1837-1917), it is more acceptable to use another less prejudiced definition of the phenomenon of "ethnic entrepreneurship" - as "an object of scientific consideration", reflecting the forms of everyday behaviour of minorities.

In this context, if the study is limited to "ethnic territory", ethnic entrepreneurship in its content is identical to those forms of behaviour that are included in the categories of "traditional handicraft production", "traditional economic specialization", "traditional life-support and environmental management systems", "tradition system of subsistence" disclosed in the American, Western and Russian historiography on indigenous peoples ("natives"). The expansion of the subject field of field research, objectively, contributes to the expansion of field research tools, the development of algorithms (a set of techniques) of ethnological examinations [13]. These approaches are determined by the analysis of the phenomenon of ethnic entrepreneurship as a sustainable system of social communications between rural enclaves and urban diasporas based on the concepts of network and fractal social organization [14]. The conducted studies determine the assessment of ethnic entrepreneurship as a mechanism (a set of causal relationships) to preserve not only ethnic self-identification but also traditional culture [15].

Indeed when we visited the Navajo reservation in Arizona in 1998 in their stylish small modern terraces we found that they had even lost their traditional foods while the Zuni stone fetish carvers had experienced a renaissance of identified artists [16]. Associated studies are sufficient, and of interest in terms of using the developed research tools to analyze the transformation processes of traditional forms of economic activity of local ethnic groups under the influence of state policy. As a separate field of investigation, there are issues related to the development of the recreational potential 
of national regions in tandem with the aim of preserving the natural, historical and cultural heritage. This is the context of globalization of culture and cultural identity.

Thus, heritage objects and state-stimulated forms of ethnic entrepreneurship are considered as a "brand" of the territory, its ethnic specificity, which underwrites the sustainability of tourist flows.

Particular attention should accordingly be given to such a phenomenon as folklore which can be considered as a process of communicating folk culture as a product of trade and market relations, and so an element of the "tourism industry".

The demonstration of folklore as a performance, (for example Taffy Thomas of the Wonderful Cloak of over 300 folktales is the professional storyteller of Grasmere in Cumbria UK) the sale of folklore products characteristic of the area in order to attract tourists, is an important benefit in the study of folklore.

On the other hand, the organic process of adaptation, transformation and reproduction of folklore in the culture of modern society was identified by Hermann Bausinger [17].

A practical result of this concept is integrated development programs for individual areas acknowledging the role of local communities in their implementation. This gives an academic analysis of Harald Bohmer's fundamental support of the natural dye carpet weaving DOBAG project in Ayvacuk Western Anatolia in Turkey.

In general, it can be noted that the algorithm in a systematic approach to the analysis of traditional ethnic specialization and the "informal economy" in the USA, Canada, and Russia was the result of integration studies from the perspective of ethnography, sociology, history, and economics.

In this regard, a comparative analysis, the use of approaches and methods tested in non-Russian publications will help to better understand the historical and ethnocultural conditioning, namely the root causes of social and economic processes of the culturally complex north Caucasus region. It refers to its hierarchically subordinate characteristic system of intra-regional and inter-regional ties.

We rely on the methods and experiments tested in studies of various mountain regions of the world in determining research on the recreational development of the North Caucasus. But no less important is the collection of specific local materials and information. Their analysis

will reveal:

a) life sustainability models based on the traditional ethnic economic specialization of the indigenous population, preserving the ethnic territory and traditional social institutions;

b) indicators of the resource potential of sustainable rural development retaining its traditional economic specialization;

c) scenarios of the formation of diasporas and the integration of migrants in the regional and urban economies;

d) systems of interconnections uniting urban diasporas and rural enclaves;

e) mechanisms for the formation of inter-regional ties, which give stability to the ethnic economy; 
f) criteria for the level of preservation of traditional culture.

In Daghestan, an instructive example is Kubachi's role as a decorative weapon and silver workers since 1870 s after the Tsarist conquest onwards to its participation in international exhibitions, representing Russia.

Due to the multi-ethnic composition of the population of the Russian Federation and the differences in the levels of socio-economic development of its regions, the issues raised are of interest not only in the Caucasus, but in all areas of the country that see a source of sustainable development exclusively in the development of the recreational potential of the territory and the use of ethnic identity as "brand" potential negative, and sadly often negative effects. In this regard, the task of determining indicators, criteria, the formation of a "regulation" or formalized procedures that allow monitoring of the ethnosocial situation, the change of which, as international practice shows, poses risks for the development of the tourism industry, remains relevant. Regarding the North Caucasus, any successes and risks in the tourism sector are unrealistic if processes of environmental degradation are continuing. This refers to inter alia cultural landscapes, historical, cultural and natural heritage, traditional life support systems, economic specialization, handicraft centres, ethnographic "brands" in artistic, gastronomic, and other fields. Degradation occurs if social ties aimed at preserving ethnic identity based on the preservation of traditional life support systems, local economic specialization and social institutions are weakening.

The chosen systematic approach determines the following main methodological principles:

a) identification of system-forming relationships and substantiation of integrity;

b) determination of the hierarchical subordination of social connections;

c) determination of the nature of the impact of the external environment (changing policies, population structure, resource basis);

d) determination of the mechanism (cause-effect relationships) transformation of traditional institutions under the influence of the environment.

To increase the significance of the expected results during the implementation of the project, it is advisable to:

a) use a selective approach in the study of the phenomenon of "ethnic entrepreneurship". We study specific mountain clusters (rural communities/craft centres);

b) the study of social ties in the context of ethnocultural and socio-structural dynamics in several chronological bands.

Note that during the period of modernization of Russian society during the late 19th to early 21st centuries several chronological bands can be identified, within which framework there have been changes in the backbone of social ties. For rural areas the most obvious are the periods of administrative-territorial reforms, the implementation of recreational development programs, [for example in 19th century: mineral spa resorts, sanitoria and jewellery shopping visits to Kubachi] periods of aggravation of interethnic relations that affect migration flows and changes in the social structure of the population $[18 ; 19]$. 
Discussion of the algorithm (sequence of logical operations) of selecting research sites and chronological sections and evaluating the representativeness of the information obtained from them, will be studied elsewhere. The process approach to be implemented is planned by the analysis of sample ethnic enterprises (rural communities) as business entities. The current activity and the system of external relations (communication with the various environments described below) are reflected in the "production cycle".

This study, unlike traditional approaches, is not focused solely on the analysis of the economic activities of migrants in the system of social institutions of the host urban community. Rather it is viewed from the standpoint of social anthropology, a science where various forms of group economic behaviour act as one of the most important "components" of the complex communication ties that form the image of the "ethnic culture" of everyday life. In this regard, the subject area of research includes analysis of social processes linked to the adaptation of ethnic communities to environmental changes at different stages of 'modernization'.

Adaptation processes focus on the reaction of autochthonous groups (i.e. mountain clusters and rural communities of Dagestan) that have retained traditional life-support systems, economic specialization, usually in craft centres in the lengthy process of modernization of the Russian state (late 19th-early 21st centuries) and the natural and social environment. We also focused on identifying and recording both trends and facts of changes (reorganization) of social ties in the structure of traditional social institutions, inter alia multi-generational family, territorial-community organization / and community. We identify the role of these ties in maintaining a stable ethnic economy in the conditions of Dagestan (mountain clusters), regardless of successive changes in the state system and political regimes. Here, the preservation of the traditional economic specialization of ethnic groups is far from the "struggle" for a monopoly position in the regional market of goods and services, or the situation of destabilization of the ethnosocial situation in the district as a whole. This process organically fits into the spectrum of both intra- and inter-regional communication ties (i.e. production, distribution, political, confessional, etc.), covering various social institutions (including authorities) and population groups. The above are important observations when deploying a network of regional ethnological monitoring, at the formation and implementation of the National Policy Strategy, aimed only to a certain extent at ensuring security in the region and sometimes cosmetically based on the UN Sustainable Development Goals (https://sustainabledevelopment. un.org/?menu=1300). An interesting comparison is Brazil driving out Amazonia indigents and destroying the rain forests is also signed up to the UN goals.

Understanding of traditions, popular experience in the development of mountainous areas as transforming under the influence of various factors, the NPS norm allows investing in the following: new social, cultural and landscape meanings in the well-known legal, economic, agro-technical, geographical, environmental and other interpretations of the socio-economic and ecological development of the environment, discover new research perspectives that appear in the description: 
a) methodological and applied problems of using ethnocultural (including ethnoeconomics and environmental experience) traditions in the formation and implementation of strategies for the socio-economic and environmental development of mountain territories;

b) the current socio-economic, ethnocultural, environmental situation, understood as the result of natural and artificial changes in the landscapes, economic activity, material culture, social structure.

In Russian and non-Russian publications on the development of mountainous areas mainly general theoretical, economic, geographical, environmental, less often demographic issues are considered. Frequently ethnocultural aspects of mountain development problems are at best considered secondary if at all. As far as ethnoecology and ethnoeconomics are concerned in Daghestan or the rest of the North Caucasus, these scientific fields of ethnology have not yet been addressed. The relevance of the study of the demographic history of Dagestan is concerned with the progressive depopulation of mountain regions.

\section{Demographic issues}

A review of the historiography of migrations from the mountainous territories of Dagestan to the flatlands, which occurred mainly in the Soviet and post-Soviet periods, shows that the root causes of this process in Soviet times were defined as economic feasibility, called "internationalization" of all spheres of life. From the command-administrative destruction of the natural course of migration processes, from the forced formation in the plains of multinational regions and settlements, the republic only 'gained' long-term social and interethnic problems. However, over the past three decades, the direction of an understanding of the resettlement issue has unfolded completely opposite from "internationalization". The Highlanders i.e. mountaineers who moved to the plain not of their own free will, but according to "Soviet law", began to be perceived as the culprits of interethnic conflicts, violators of the Sharia, who, as Muslims were considered haram forbidden because they live in "foreign lands", occupy "foreign ethnic territories" and so infringe on the "national interests of indigenous peoples." And this is not a "thickening of colours", but a negative subtext which, contrary to their veiled terminological balancing act and pseudo-scientific turns of ambiguity, are found in the majority of post-Soviet publications on Dagestani migrants. Meanwhile, the demographic, ethnocultural consequences of migrations from the mountains to the plain for Dagestan as a whole and for its mountainous regions, in particular, have not yet become the subject of serious scientific analysis.

An understanding of the native land as a territory for the formation of ethnic communities, as a category uniting states in a nation, is based on the constructive recognition of the role of state concepts of national identity in nation-building. Ethnically complex states regard their regions merely as administrative-territorial units but not much as a "spiritualized" historical memory, which, along with the 
mother tongue, is an objective component of ethnic identity and the primary basis of patriotism, the degree of strength of which determines, in our opinion, the degree of strength of civic identity, the consciousness of belonging to a political nation. In this regard, what legal and ethnosocial consequences can be expected from periodic pejorative reminders in the media, publications, and everyday communication of highland migrants to the plains now second to fifth generations old, about the fact that they live in "foreign ethnic territory"? Is this to unify Dagestan society or to strengthen All-Russian Civil Identity? How can territorial conflicts be resolved in court, without increasing inter-ethnic tensions?

We note that in relevant 2oth-century publications the historical aspects of the problem are often ignored. For Dagestan, as well as for the whole of Russia, this is a period of well-documented heavy demographic losses associated with the First World War, the Civil War and the Great Patriotic War. In addition, censorship, repression and physical extermination of clergy in 1928-1938, forcible resettlement of a fifth of the highlanders on the territory of the abolished Chechen-Ingush Republic and the Aukhov district of Dagestan, again after the repatriation of Chechens in 1957-1958, the resettlement of Dagestanis from Chechnya to their homeland all damaged the social well-being of the peoples of Dagestan.

The social problems caused by wartime difficulties and famine were further aggravated by the fact that among the displaced people, because of the unusual climate of the plains in mountain villages, fatal epidemics of malaria, dysentery and other infectious diseases became more frequent. Despite adherence to the traditional way of life in the mountainous ecological environment, the majority of the Daghestani who returned from Chechnya to Chechnya home in 1958 had no better choice than to take advantage of the material preferences offered by the government and settle down in the lowlands of Dagestan.

As a result of the mass resettlement of inhabitants of the mountainous regions of Dagestan to the Caspian lowland, which Rasul Gamzatov called changing Mountaineers into Fishermen, which began in the 1920 and continued until the mid-1960s, as well as the rapid growth of the urban population in the 1970 and subsequent years, the population of highlands decreased to critical levels, as defined by Joanna Nicholls as colonies of less than 1000 inhabitants. And this despite the fact that in conditions of total ethnic mixing and assimilation processes on the plain and in the cities where two-thirds of the three millions population of the Republic of Dagestan live, the highlands still seem to and will remain the most important factor in preserving the ethnocultural identity of the peoples of Dagestan. However, there are fewer and fewer grounds for optimism in this regard. Dozens of abandoned "ghost villages" appeared in the mountainous parts of Dagestan. More than 90 thousand hectares of mountain terraced fields were forcibly abandoned. Many local varieties of agricultural crops adapted to local conditions disappeared. They included mountain and mountain-valley corn, frost-resistant bare-grain barley, durum wheat varieties Sary-Bugda and Ak-Bugda, dozens of varieties of fruits and vegetables and natural medicines. At the same time, there is degeneration of breeds of cattle, sheep, goats, 
horses, bred for centuries and highly adapted to the harsh mountain conditions

The problems of monetizing abandoned mountain terraced arable lands and garden plots remain unresolved. In detail there is scant implementation providing farmers with small-scale mechanization tools such as mini tractors, cultivators, mowing machines, etc., creating consumer cooperatives, revising the pricing policy for mountainous, better, more environmentally friendly ones remain unresolved. Not even considered are the first steps of the restoration of traditional forms of animal husbandry, terraced farming, the expansion of horticulture and traditional crafts; the creation of a full-fledged social infrastructure including road network, communications, transport, gasification, energy supply, etc.) Without the above to equalize the qualities of life of highlanders and residents of the plains, overcoming the demographic depression of the mountainous territories of Dagestan is impossible.

More than two hundred mountain villages and hamlets, a large number of terraced fields, orchards, agricultural land became abandoned. Today, to repeat, two-thirds of the three million population of the Republic of Dagestan are concentrated in the Caspian regions and cities, in conditions of exceptional ethnic confusion and growing conflict potential, as well as extremely limited opportunities to preserve linguistic and ethnocultural identity.

In the post-Soviet period almost half-million population, two times as many highlanders migrated from the mountains to the plain and to the cities than during all the Soviet years (250 thousand people). During the same post-Soviet period, the population of Makhachkala has tripled, populated by almost every third resident of Dagestan. Illusory statements are made about the inexhaustible potential of the Dagestan village in the sense of preserving the ethnocultural image and native languages, as well as the positive experience of the social and economic organization of life in the mountains [20]. In this regard, scientific studies devoted to the study of mountain territories are directly or indirectly related not only to the strategic priorities of the mountain policy of the Russian Federation. They also claim to preserve of the ethnocultural identity of the mountain territories, the effective use of the demographic potential of these territories in order to solve urgent problems of socio-economic and environmental development of mountain regions and the country as a whole.

To judge from the popularity of the thesis, which still needs to be checked, that in recent centuries the hotbeds of geopolitical instability have ripened in mountainous countries, as well as the destructive geological metaphor of activating the movement of "cultural-civilization [tectonic] plates" and, accordingly, aggravating the geopolitical situation at their junctions, studies of a humanitarian orientation can have important socio-political significance.

A study of the socio-adaptive, economic and environmental problems of the transformation of mountain landscapes and the lifestyle of the population of the largest and most multinational region of the North Caucasus, which is the Republic of Dagestan, should serve as information and methodological support for researches on forecasting and strategic development of the mountain regions of the Russian Federation. 


\section{Consequences of Soviet Social and Demographic Engineering}

The natural conditions of the both Mountain and Lowland country, with its abundant alpine pastures and fruitful gardens of mountain valleys, with vast winter pastures on the plain and fertile coastallands, allowed the population, whosepopulation of Dagestan probably never exceeded 4 million people, to provide themselves with a decent life. As for the depictions about the severity of living conditions in the mountains and hot valleys of Dagestan, legends, such as the one that tells about the mountaineer's tiny arable land lost under a burka, are 19th-century folklore which began to take on the meaning of economic and political speculation, glossing over the destructive long war against Russia under Shamil from 1831 to 1859. In Dagestan, the economic problems of livelihoods in conditions of natural mountain landscapes, the imbalance between grazing and cropland was minimized due to zonal (Mountains to Plains) and international trade, mountain terraced farming and mountainvalley gardening, an ancient tradition. The intensity and technological perfection of mountain horticulture were said to be an achievement of world significance in the field of economic and economic development of mountain landscapes.

The traditional system of land tenure and land use for Dagestan contained positive principles in terms of social justice. The balance of interests of the rural community and each of its citizens was ensured by:

a) the sovereign rights of the community over the entire territory of the rural community, marked for each boundary;

b) equal rights of any adult and mentally healthy member of the community for the acquisition of land property, and for the use of communal land. The unity of the rural community was the observance in the society of the principle of priority of the interests of the community over private interests.

Unlike technological innovations, which were learned from Russian settlers mainly in the lowland areas of Dagestan, the land-use procedure continued to retain conservative features and tradition. Soviet power having eliminated private ownership of land, turning public lands into a semblance of public lands, and the collective farm system (Kolkhoz/ Sovkhoz) radically changed the economic foundations of Dagestan society. The social consequences of the collectivization of agriculture and the "elimination of the kulaks as a class" (Kulaks were perceived to be rich peasants running independent economic units such as a kitchen garden that had been destroyed to save the owner who we visited in 1985 in Botlikh) for Dagestan with its predominantly rural population are well-known. Thousands of families were deprived of their property or evicted outside their native villages or outside Dagestan, mainly to Kyrgyzstan. The inevitable moral costs that encompassed the sixth part of our planet in the social and economic experiment, expressed, in particular, in relation to collective farmland as "no man's land", also occurred in Dagestan. Nevertheless, the Dagestanis, compelled to reconcile with the loss of private, "family" lands, nevertheless continued to maintain consciousness and understanding of the eternal stewardship of the territory of their rural community. 
The transition from a state of stagnation (zastoy) and incomplete perestroika to the stage of total destruction of the old political and community system affected practically all spheres of society. Quality of life statistics in Dagestan presented a gloomy picture even in comparison with other depressed regions of the Russian Federation. Rich in natural and labour resources, the republic had a budget of up to 90 per cent funded through subsidies from Moscow. The average per capita income in Dagestan was/ is one-third of that for Russia. Of the more than 800,000 people in the economically active population, one in five did not have permanent jobs, excluding the grey economy. In the 1990s, of the approximately 2 million present population of Dagestan, more than $40 \%$ were in rural areas with a low level of mechanization of agricultural production and seasonal employment. About 700 thousand Dagestanis lived outside the Republic of Dagestan. Before the collapse of the USSR, it was vital that from March to November, more than 300,000 Dagestan men in brigades migrated to work in different parts of the Soviet Union. However, the aggravation of interethnic relations in the former republics of the USSR and certain regions of the successor Russian Federation, and the discrimination against "people of Caucasian nationality" were a serious obstacle to the labour and educational migration of Dagestanis outside the Republic of Dagestan. For example, thousands of families of Dagestanis who worked for decades as sheep farmers in Kalmykia, the Stavropol Territory, and also in the Volgograd and Rostov Regions returned home with their families to Dagestan due to inter-ethnic tension, often provoked by municipal authorities.

In the 1990s, intentional neglect of traditional moral ideals and values, an attack of nationalist and extremist ideology on the public consciousness, and links with criminal morality acquired an unprecedented profile in the history of Dagestan. Against this background, there re-emerged wealthy nation-wide and collective- state farm property-owners with luxurious fortified houses with European-quality fittings, Mercedes cars and other status symbols, who suddenly got rich on privatization. This was accompanied by summary sackings of workers, engineers, office workers at the factory gates and corruption into all socially significant spheres, including the higher education system. These and other phenomena became characteristic of the whole country and determined the social differentiation of Dagestan society into masses of social outsiders and two to three hundred rich family-clans who tidied up everything. The people survived as best they could. The material well-being of ordinary families was ensured largely thanks to the shuttle business, described below and other trading activities. A significant part of urban families was fed by-products from relatives from native villages. The country's light and textile industries were in collapse. Eighty-five per cent of consumer goods sold on the Dagestan market were imports from Turkey, China, the United Arab Emirates, Iran, the Czech Republic, and Poland. Contrary to Islamic regulations forbidding women to travel unaccompanied by husbands or close relatives, the bulk of the so-called "shuttles" were women, and they were the majority of traders in markets and bazaars.

Nationalist and semi-criminal groups and individuals with a low level of political 
culture, ostentatious piety and genuine concerns about obtaining resources for material and information support of ethnic solidarity around their own people, about access to power and profitable places, began to claim the role of spokesmen for the aspirations of the people.

At the Russian Investment Forum, which took place in Sochi on February 14-15, 2019, the Minister of the Russian Federation for North Caucasus Affairs Sergey V. Chebotarev said that, on the initiative of the Ministry, a model law "On Development for the Protection of Mountain Territories" is being developed. According to him, the basis of the law "will lie a simple thing: what is located above 1.5 thousand meters, what is registered there, above 1.5 thousand meters, what is produced there should be subject to benefits. In fact "This is such a special economic zone, which is located in the mountains." He also said that the introduction of a preferential regime should help stop the outflow of people from the mountainous territories, that "About $60 \%$ of the territory of the North Caucasus Federal District is mountainous territories. Therefore, of course, we see the need for the additional legal regulation of these territories. We take into account the experience of Western states, in particular, "We talked with our Austrian colleagues who have a similar law, it is functioning, and it is functioning efficiently." He also noted that the development of the economy in the mountains should not affect the traditional mountain culture and lifestyle that remained in the highlands of the North Caucasus (https://vestikavkaza.ru/news/CHebotarev-zakono-gornykh-territoriyakh-pomozhet-sokratit-ottok-naseleniya.html).

\section{Summary and Conclusion}

Dagestan is geologically divided into lowlands, foothills and highlands. A special feature of the high-mountainous landscapes of Dagestan is that the Main Caucasus Range along its entire length - more than $300 \mathrm{~km}$ - is cut by large rivers into several basin zones, which are characterized by exceptional agro-ecological and ethnocultural diversity. These factors created the geography of the predominant occupation of agriculture in the plains and cattle breeding in the high-mountainous regions of Dagestan.

The problem of the state of nature and natural resources of mountainous areas is, first of all, the problem of the ecological, socio-cultural and economic well-being of the inhabitants of the mountains.

The consequence of the mass resettlement of residents of high-mountainous regions of Dagestan to the Caspian lowland since the 1920s, the growth rate of the urban population increase since the 1950 s became the prime factor in weakening the anthropogenic impact on mountain landscapes. At the same time, with the total ethnic mixing of the population on the plains and in the cities of Dagestan, the highlands remain the primary factor in the preservation of ethnocultural identity. Thus the depopulation of the highlands can have serious ethnic and cultural assimilation consequences.

In the highland areas, over 90 thousand hectares terraced fields remain aban- 
doned. Many agricultural varieties cultivated for centuries and most-adapted to local conditions (mountain and mountain-valley maize, cold-resistant and bare-grain mountain barley, durum wheat "sary-bugda" and "ak-bugda", many other varieties of fruits and vegetables) are disappearing. There is a degradation of local livestock breeds, adapted for centuries to the harsh mountain conditions. Examples include Dargin and Avar fat-tailed sheep, local breeds of cattle, and horses. It is known that the cost of production on mountain pastures is higher than on the plains since in the mountains the harsher winter conditions mean that the period of stall maintenance of livestock is longer. An extreme example is Archi and Bezhta which are snowed off between October and March.

Since the collapse of USSR a lot of programs of social and economic development of mountain territories of the Republic of Dagestan. There is no reason to disassemble the contents of these programs, more to the protocols of intents than to implementation mechanisms.

It is necessary to solve the problems of monetizing abandoned mountain terraced arable lands and garden plots. This involves strengthening the material and technical infrastructure of producers by providing small-scale mechanization (mini tractors, tillers, mowing machines, etc.), creating consumer cooperatives, revising the price policy for "mountain", more qualitative, ecologically pure agricultural products.

Equally important are the issues of restoring the traditional foundations of animal husbandry, terraced farming, the expansion of gardening and traditional crafts; creation of a full-fledged social infrastructure (road network, communications, transportation, gasification, energy supply, etc.), without which a socio-economic revival and development of the mountain areas, levelling the quality of life of the mountaineers and the inhabitants of the plain are impossible.

Future planning must include a projection of the effects of global warming both on the reduction of snow cover of the high mountains and the damage of a rise in the Caspian sea level and its effect on the capital Makhachkala and the main tourist destination of Derbent.

Undoubtedly, the implementation of these measures will contribute to overcoming negative trends, reducing the depopulation in alpine regions, and ensuring the socio-economic and cultural 1 revival of the peoples of Dagestan.

Aknowledgment: The study was supported by the Russian Foundation. basic research in the framework of the Russian Foundation for Basic Research (RFBR) project 19-09-00490 A "The use of ethno-cultural traditions in the strategy of social, economic and environmental development of the mountain territories of Dagestan. "

Благодарность: Исследование выполнено при финансовой поддержке Российского фонда фундаментальных исследований в рамках проекта РФФИ 19о9-00490 А «Использование этнокультурных традиций в стратегии социальноэкономического и экологического развития горных территорий Дагестана». 


\section{REFERENCES}

1. Light I., Karageorgis S. The Ethnic Economy N. Smelser, R. Swedberg (eds.), The Handbook of Economic Sociology, Princeton University Press, Princeton 1994: 646-671.

2. Mark S. Granovetter. The Strength of Weak Ties The American Journal of Sociology, Vol. 78, No. 6 (May 1973): 1360-1380. Published by: The University of Chicago Press Stable URL: http://www.jstor.org/stable/2776392. https:// docviewer.yandex.ru/view/681977626/

3. Ethnic groups and boundaries: The social organization of culture difference / Ed. by F. Barth. Universitets for laget AS, Oslo, 1969.

4. Ceri Peach, Vaughan Robinson and Susan Smith (eds), Ethnic Segregation in Cities, Croom Helm, London, 1981.

5. Bonacich EA Theory of Middleman Minorities American Sociological Review, Vol. 38, No. 5. (Oct. 1973): 58-594, URL: http://www. scribd.com/doc/20267636/Bonacich-A-Theory-of-Middleman-Minorities

6.Waldinger R. Ethnic Business and Occupational Mobility in Advanced Societies, Sociology / R. Waldinger, R. Ward, H. Aldrich. 1985. Vol. 19, № 4: 586-597.

7. Waldinger R. Immigrant enterprise. A critique and reformulation / R. Waldinger Theory and Society. 1986. Vol. 15. № 1: 249-285.

8. Radaev VV. Ethic entrepreneurship: Russia and the global experience [Etnicheskoe predprinimatelstvo: Rossia i mirovoi opyt] Polis. 1993. № 5: 79-87.

9. Ryzhova NP. Ethnic entrepreneurship phenomenon: western tradition and Russian perusal [Fenomen etnicheskogo predprinimatel'stva: zapadnaya traditsiya i rossiyskoye prochteniye] Modern humanitarian studies [Novyye gumanitarnyye issledovaniya]. № 3. 2008. Ethnology. URL: http://www.nrgumis.ru/articles/article_ full.php?aid=77 [доступ 2012.08.10]

10. Snisarenko A. Ethic entrepreneurship in a large city of modern Russia (on the case of Azerbaijan community in St. Petersburg [Etnicheskoye predprinimatel'stvo $\mathrm{v}$ bol'shom gorode sovremennoy Rossii (na primere issledovaniya azerbaydzhanskoy obshchiny v Peterburge)] Neformalnaya economika. Rossiya i mir. ed. T. Shanin. M.: Logos, 1999: 138-155.

11. Grigoreva KS., Mukomel VI. Tasks and realization of reforms of the migration legislation: migration registration, regional authority, corruption risks, budget income [Zadachi i realizatsiya reform migratsionnogo zakonodatel'stva: migratsionnyy uchet, polnomochiya regionov,

\section{СПИСОК ЛИТЕРАТУРЫ}

1. Light I., Karageorgis $S$. The Ethnic Economy, [in:] N. Smelser, R. Swedberg (eds.), The Handbook of Economic Sociology, Princeton University Press, Princeton 1994, P. 646-671.

2. Mark S. Granovetter The Strength of Weak Ties // The American Journal of Sociology, Vol. 78, No. 6 (May 1973), pp. 1360-1380. Published by: The University of Chicago Press Stable URL: http://www.jstor.org/stable/2776392. https://docviewer.yandex.ru/view/681977626/

3. Ethnic groups and boundaries: The social organization of culture difference / Ed. by F. Barth. Universitets for laget AS, Oslo, 1969.

4. Ceri Peach, Vaughan Robinson and Susan Smith (eds), Ethnic Segregation in Cities, Croom Helm, London, 1981. 258 pp.

5. Bonacich E.A Theory of Middleman Minorities In. American Sociological Review", Vol. 38, No. 5. (Oct. 1973), s. 58-594, URL: http://www.scribd.com/doc/20267636/Bonacich-A-Theory-of-Middleman-Minorities

6.Waldinger R. Ethnic Business and Occupational Mobility in Advanced Societies, Sociology / R. Waldinger, R. Ward, H. Aldrich. 1985. Vol. 19, № 4. Pp. 586--597.

7. Waldinger $R$. Immigrant enterprise. A critique and reformulation / R. Waldinger // Theory and Society. 1986. Vol. 15. № 1. Pp. 249-285.

8. Радаев В.В. Этническое предпринимательство: Россия и мировой опыт // Полис. 1993. № 5. C. 79-87.

9. Рыжсва Н.П. Феномен этнического предпринимательства: западная традиция и российское прочтение. // Новые гуманитарные исследования. № 3. 2008. Этнология. URL: http://www.nrgumis.ru/articles/article full.php?aid=77 [доступ 2012.08.10]

10. Снисаренко A. Этническое предпринимательство в большом городе современной России (на примере исследования азербайджанской общины в Петербурге) // Неформальная экономика. Россия и мир / Под ред. Т. Шанина. М.: Логос, 1999. С. 138-155.

11. Григорьева К.С., Мукомель В.И. Задачи и реализация реформ миграционного законодательства: миграционный учет, полномочия регионов, коррупционные риски, доходы бюджетов // Миграционное право. 2018. № 2. C. $3^{-8}$.

12. Вендина О.И. Дагестан: традиция как 
korruptsionnyye riski, dokhody byudzhetov] $M i$ gratsionnoe parvo. 2018. № 2: 3-8.

12. Vendian OI. Dagestan: traditions as a term of modernization [Dagestan: traditsiya kak usloviye modernizatsii] Nauka. Innovatsii. Tekhnologii. 2016. № 3: 137-163.

13. Poddubikov VV., Sadovoy AN., Belozerova M.V. Examination and monitoring of traditional forms of environmental management of indigenous minorities: methods of applied ethnology [Ekspertiza i monitoring traditsionnykh form prirodopol'zovaniya korennykh malochislennykh etnosov: metody prikladnoy etnologii]. Kemerovo: LLC «Practice», 2014.

14. Sadovoy AN. Methodological aspects of the analysis of traditional forms of ethnic entrepreneurship [Metodologicheskiye aspekty analiza traditsionnykh form etnicheskogo predprinimatel'stva] Nauchnyy dialog. 2019. № 8: 345-359.

15 Sadovoy AN., Belozerova MV. Ethnic economics in mountain ecosystems. Methodological aspects of the analysis of traditional systems of social communications Actual directions of the balanced development of mountain territories in the context of an interdisciplinary approach: proceedings of the I International Scientific Conference. Karachaevsk: KCHU, 2019: 213-218.

16. Bahti M. Spirit in the Stone. Tuscon, 1999.

17. Herman B., Intercultural Demands and Cultural Identity [in] Language, Culture and Identity, Language \& Cultural Contact, Aalborg University Press. 1999: $11-23$.

18. Magomedkhanov MM. Dagestanis: milestones of ethnosocial history [Dagestantsy: vekhi etnosotsial'noy istorii]. Makhachkala, 2007.

19. Magomedkhanov MM., Bakanov AV., Garunova S.M. Changes in social relations during the military-public administration of the Dagestan region of the Russian Empire [Izmeneniya $\mathrm{v}$ sotsial'nykh otnosheniyakh $\mathrm{v}$ period voyenno-narodnogo upravleniya Dagestanskoy oblast'yu Rossiyskoy imperii] Klio. 2019. № 7 (151): 91-97.

20. Ibragimov M-RA., Magomedkhanov MM. Ethno-demographic aspects of the formation of the urban population of Dagestan (second half of the 19th - beginning of the 21th century) [Etnodemograficheskiye aspekty formirovaniya gorodskogo naseleniya Dagestana (vtoraya polovina XIX - nachalo XXI v.) Bulletin of St. Petersburg University. History. 2009. № 1: 247-259. условие модернизации // Наука. Инновации. Технологии. 2016. № 3. С. 137-163.

13. Поддубиков В.В., Садовой А.Н., Белозерова М.В. Экспертиза и мониторинг традиционных форм природопользования коренных малочисленных этносов: методы прикладной этнологии. Кемерово: ООО «Практика», 2014. - $358 \mathrm{c}$.

14. Садовой А.Н. Методологические аспекты анализа традиционных форм этнического предпринимательства // Научный диалог. 2019. № 8. С. 345-359.

15. Садовой А.Н., Белозерова М.В. Этническая экономика в горных экосистемах. Методические аспекты анализа традиционных систем социальных коммуникаций // Актуальные направления сбалансированного развития горных территорий в контексте междисциплинарного подхода: материалы I Международной научной конференции. Карачаевск: КЧГУ, 2019. С. 213-218.

16. Bahti $M$. Spirit in the Stone. Tuscon, 1999.

17. Herman B. Intercultural Demands and Cultural Identity [in] Language, Culture and Identity, Language \& Cultural Contact, Aalborg University Press, pp. 11 - 23, 1999

18. Магомедханов М.М. Дагестанцы: вехи этносоциальной истории. Махачкала, 2007. $256 \mathrm{c}$.

19. Магомедханов М.М., Баканов А.В., Гарунова C.M. Изменения в социальных отношениях в период военно-народного управления Дагестанской областью Российской империи // Клио. 2019. № 7 (151). С. 91-97.

20. Ибрагимов М.-Р.А., Магомедханов M.M. Этнодемографические аспекты формирования городского населения Дагестана (вторая половина XIX - начало XXI в.) // Вестник Санкт-Петербургского университета. История. 2009. № 1. С. 247-259.

Статья поступила в редакцию 10.12.2019 2. 